\title{
Effects of $\mathrm{GeO}_{2}$ on chlorophyll fluorescence and antioxidant enzymes in apple leaves under strong light
}

\author{
Z.B. WANG ${ }^{*}$, Y.F. WANG*, J.J. ZHAO*, L. MA*, Y.J. WANG ${ }^{*}$, X. ZHANG ${ }^{*}$, Y.T. NIE*, Y.P. GUO ${ }^{* * *,+}$, \\ L.X. MEI, and Z.Y. ZHAO ${ }^{*, * * *}$ \\ College of Horticulture, Northwest A\&F University, Yangling, Shaanxi, China* \\ Key Laboratory of Horticulture Plant Biology and Germplasm Innovation in Northwest China, \\ Ministry of Agriculture, Northwest A\&F University, Yangling, Shaanxi, China ${ }^{* *}$ \\ Shaanxi Engineering Research Center for Apple, Yangling, Shaanxi, China ${ }^{* * *}$
}

\begin{abstract}
In this study, we chose apple leaf as plant material and studied effects of $\mathrm{GeO}_{2}$ on operation of photosynthetic apparatus and antioxidant enzyme activities under strong light. When exogenous $\mathrm{GeO}_{2}$ concentration was below $5.0 \mathrm{mg} \mathrm{L}^{-1}$, maximum photochemical quantum yield of PSII and actual quantum yield of PSII photochemistry increased significantly compared with the control under irradiances of 800 and $1,600 \mu \mathrm{mol}$ (photon) $\mathrm{m}^{-2} \mathrm{~s}^{-1}$. Photosynthetic electron transport chain capacity between $\mathrm{Q}_{\mathrm{A}}-\mathrm{Q}_{\mathrm{B}}, \mathrm{Q}_{\mathrm{A}}-\mathrm{PSI}$ acceptor, and $\mathrm{Q}_{\mathrm{B}}-\mathrm{PSI}$ acceptor showed a trend of rising up with 1.0, 2.0, and $5.0 \mathrm{mg}\left(\mathrm{GeO}_{2}\right) \mathrm{L}^{-1}$ and declining with $10.0 \mathrm{mg}\left(\mathrm{GeO}_{2}\right) \mathrm{L}^{-1}$. On the other hand, dissipated energy via both $\Delta \mathrm{pH}$ and xanthophyll cycle decreased remarkably compared with the control when $\mathrm{GeO}_{2}$ concentration was below $5.0 \mathrm{mg} \mathrm{L}^{-1}$. Our results suggested that low concentrations of $\mathrm{GeO}_{2}$ could alleviate photoinhibition and $5.0 \mathrm{mg}\left(\mathrm{GeO}_{2}\right) \mathrm{L}^{-1}$ was the most effective. In addition, we found, owing to exogenous $\mathrm{GeO}_{2}$ treatment, that the main form of this element in apple leaves was organic germanium, which means chemical conversion of germanium happened. The organic germanium might be helpful to allay photoinhibition due to its function of scavenging free radicals and lowering accumulation of reactive oxygen species, which was proven by higher antioxidant enzyme activities.
\end{abstract}

Additional key words: chlorophyll fluorescence; irradiance; photodamage; photosynthetic electron transport chain.

\section{Introduction}

Germanium (Ge), a rare element, belongs to the fourth group of the periodic table along with carbon (C), silicon $(\mathrm{Si})$, tin $(\mathrm{Sn})$, and lead $(\mathrm{Pb})$. It exists in the Earth's crust (approximately $1.6 \mathrm{mg} \mathrm{kg}^{-1}$ ) and has dual nature of metal and nonmetal. Ge can be divided into general inorganic compounds including elemental germanium, $\mathrm{GeO}_{2}$, and organic compounds including Ge-132, spiro-germanium and proxi-germanium (Adams and Thomas 1994, Kaplan et al. 2004). Among various kinds of $\mathrm{Ge}$, organic $\mathrm{Ge}$ has been confirmed to possess therapeutic attributes including fighting cancer and improving the immune system in human and animals and it was further concluded that the change was attributed to raising radical scavenging activity (Goodman 1988, Tang et al. 1997, Yang and Kim 1999).

Received 6 April 2016, accepted 19 June 2017, published as online-first 12 April 2018.

${ }^{+}$Corresponding author; e-mail: ypguo@nwsuaf.edu.cn

Abbreviations: ABS - absorption flux; ABS/RC - absorption flux per reaction center of PSII; $\mathrm{ABS} / \mathrm{CS}_{0}$ - absorption flux per sample cross section; APX - ascorbate peroxidase; CAT - catalase; CS - phenomenological energy fluxes per excited cross section; DHAR dehydroascorbate reductase; $\mathrm{DI}_{0} / \mathrm{CS}_{0}$ - dissipated energy flux per sample cross section; $\mathrm{DI} / \mathrm{RC}$ - dissipated energy flux per reaction center of PSII; DM - dry mass; FM - fresh mass; $F_{M}$ - maximal fluorescence; $F_{0}$ - initial fluorescence; $F_{v} / F_{M}-$ maximum photochemical quantum yield of PSII; $\mathrm{F}_{\mathrm{V}^{\prime}} / \mathrm{F}_{\mathrm{M}^{\prime}}$ - actual photochemical efficiency; $\mathrm{F}_{\mathrm{S}}$ - steady-state fluorescence; GPX guaiacol peroxidase; GR - glutathione reductase; MDHAR - monodehydroascorbate reductase; NPQ - nonphotochemical quenching coefficient; OJIP - fast chlorophyll fluorescence transients; PETC - photosynthetic electron transport chain; POD - peroxidase; qP photochemical quenching coefficient; RC - specific energy fluxes per active PSII reaction center; ROS - reactive oxygen species; SOD - superoxide dismutase; $\mathrm{TR}_{0} / \mathrm{CS}_{0}$ - flux of energy trapping per sample cross-section; $\mathrm{TR}_{0} / \mathrm{RC}$ - flux of energy trapping per reaction center of PSII; $\mathrm{V}_{\mathrm{I}}$ - relative variable fluorescence at the I-step; $\mathrm{V}_{\mathrm{J}}$ - relative variable fluorescence at the J-step; $\Phi_{\mathrm{NO}}$ - quantum yield of non-light-induced nonphotochemical fluorescence quenching; $\Phi_{\mathrm{NPQ}}$ - quantum yield of light-induced $\Delta \mathrm{pH}$ and zeaxanthin-dependent; $\Phi_{\text {PSII }}$ - actual quantum yield of PSII photochemistry.

Acknowledgements: This work was financially supported by the National Key Technology R\&D Program (2014BAD16B06) and the project of the China Agriculture Research System (CARS-28). 
Ge exists in all biomaterials including plants and animals (Rosenberg 2009, Sparks et al. 2011). A few studies have reported the effects of Ge on plant growth and mineral nutrition uptake in barley (Halperin et al. 1995), rice (Seo et al. 1995), lettuce (Cheong et al. 2009), Chinese cabbage (Han et al. 2007), and ginseng seedlings (Yu et al. 2005). Barley seedlings accumulated $\mathrm{Ge}$ in roots and shoots, and the shoots accumulated Ge linearly as an exogenous Ge concentration increased (Halperin et al. 1995). In hydroponically-grown lettuce treated with a low concentration of $\mathrm{GeO}_{2}$, Ge was taken up by roots and barely moved to shoots. Furthermore, with all types of Ge treatment, plants showed no changes in their phenotype of leaf shape and color, including necrosis or chlorosis (Han et al. 2007).

Although several previous studies have reported the toxicity and uptake of $\mathrm{Ge}$ in plants and explored the effects of $\mathrm{Ge}$ on photosynthesis and antioxidant enzyme systems in leaves (Tarakhovskaya et al. 2012, Liu et al. 2016), there is still no research on the operation of photosynthetic apparatus. Various studies have demonstrated ROS accumulating more under high light intensity and excess ROS causing photoinhibition (Takahashi and Murata 2008). In biological systems, the antioxidant enzyme system plays an important role in resistance to oxidative stress and is helpful to maintain the normal biological

\section{Materials and methods}

Plant material and growth conditions: Potted threeyear-old dwarf apple (Malus domestica Borkh. cv. Red Fuji)/M26 (Malus pumila Mill.) trees were selected as test material. The experiments were conducted at Northwest A\&F University, Yangling City (3420'N, $\left.108^{\circ} 24^{\prime} \mathrm{E}\right)$, Shaanxi Province, China. All plants were grown in plastic pots (height of $38 \mathrm{~cm}$, diameter of $23 \mathrm{~cm}$ ) filled with a mixed soil (volume ratio of field topsoil to organic matter was 2:1, pH 7.5, relative soil water content of 75\%). Prior to the start of our trials, all trees were well watered and regulated daily to avoid water deficiency, diseases, and insect pests.

Treatments: In order to ensure $\mathrm{GeO}_{2}$ entry into apple leaves, the marked mature leaves were cut at the petiole and immediately dipped into water solution containing 0 , 1.0, 2.0, 5.0, and $10.0 \mathrm{mg}\left(\mathrm{GeO}_{2}\right) \mathrm{L}^{-1}$, respectively, and maintained at $25^{\circ} \mathrm{C}$ under irradiance of $20 \mu \mathrm{mol}$ (photon) $\mathrm{m}^{-2} \mathrm{~s}^{-1}$ for $24 \mathrm{~h}$. Subsequently, the leaves in each treatment were divided into two parts and exposed under two light intensities of 800 and 1,600 $\mu \mathrm{mol}$ (photon) $\mathrm{m}^{-2} \mathrm{~s}^{-1}$ for $4 \mathrm{~h}$ before the determination of the parameters.

Chl content in apple leaves: Fresh leaves $(0.1 \mathrm{~g})$ were ground in $80 \%$ acetone to extract both $\mathrm{Chl} a$ and $\mathrm{Chl} b$. The samples were kept in the dark for $24 \mathrm{~h}$ at $4^{\circ} \mathrm{C}$, and the extracts were centrifuged for $2 \mathrm{~min}$ at $3000 \mathrm{rpm}$ and then analyzed by a spectrophotometer (UV-2800, Unic, Shanghai, China). The absorbance readings were per- structure and physiological activities (Apel and Hirt 2004).

Apple, one of the most important fruits in the world, has been confirmed containing Ge in our preliminary study. In consideration of therapeutic attributes of Ge, apple may have the effect of improving antioxidant ability for humans; it indicates the urgency of the study on influences of exogenous Ge on apple trees. In this study, we chose apple leaf as the test material and tried to reveal the effects of $\mathrm{GeO}_{2}$ on operation of photosynthetic apparatus and antioxidant enzyme system under two different light intensities. Graphite furnace atomic absorption spectrometry was used to investigate the uptake, accumulation, chemical conversion of Ge in apple leaves with exogenous $\mathrm{GeO}_{2}$. Furthermore, through modulated chlorophyll (Chl) fluorescence and $\mathrm{Chl}$ fluorescence transients (OJIP), more information about the $\mathrm{P}_{680}$, electron transport between $\mathrm{P}_{680}$ and $\mathrm{P}_{700}$, and $\mathrm{P}_{700}$ (PETC) and partitioning of absorbed light energy via photochemistry and thermal dissipation processes can be obtained. Moreover, in order to explain the influence of exogenous $\mathrm{GeO}_{2}$ on apple photosynthetic apparatus, we determined activities of seven antioxidant enzymes and contents of hydrogen peroxide $\left(\mathrm{H}_{2} \mathrm{O}_{2}\right)$ and superoxide anion $\left(\mathrm{O}_{2}{ }^{-}\right)$in order to explain how exogenous $\mathrm{GeO}_{2}$ influences apple photosynthetic apparatus.

formed at $665 \mathrm{~nm}$ for $\mathrm{Chl} a$, at $649 \mathrm{~nm}$ for Chl $b$. Pigment quantities were calculated according to Lichtenthaler et al. (1987).

Ge content: The content of organic and inorganic Ge in apple leaves was determined using graphite furnace atomic absorption spectrometry, as described by McMahon et al. (2004). Plant samples were cleaned with distilled water, then oven-dried at $70^{\circ} \mathrm{C}$ for $72 \mathrm{~h}$ and ground to a fine powder with a mortar. The powder with particle size below $100 \mathrm{~mm}$ were collected for analysis. Powder $(0.1 \mathrm{~g})$ from each blade was fully carbonated and then was transformed into muffle furnace to be ashed at $600^{\circ} \mathrm{C}$ for $4 \mathrm{~h}$. Through this process, all forms of $\mathrm{Ge}$ in apple leaf converted into elemental Ge and its content can be determined as the total Ge content using graphite furnace atomic absorption spectrometry. Then free inorganic Ge in apple leaf could be obtained from another $0.1 \mathrm{~g}$ of leaf powder through water bath $\left(100^{\circ} \mathrm{C}\right)$ and its content can be determined using graphite furnace atomic absorption spectrometry. The content of organic Ge in each blade can be calculated by the difference between the content of total Ge and the content of inorganic Ge.

Modulated Chl fluorescence parameters were measured at room temperature of $25^{\circ} \mathrm{C}$ with a pulse amplitude modulation fluorometer (PAM-2500, Walz, Germany) after leaves were dark-adapted for $20 \mathrm{~min}$. The fluorometer was connected to a trifurcated fiber-optic $(2010-F)$ and to 
a computer with data acquisition software (PAM Win 3.02). The experimental protocol was basically followed according to Genty et al. (1989).

The minimum fluorescence $\left(\mathrm{F}_{0}\right)$ and maximum fluorescence $\left(\mathrm{F}_{\mathrm{M}}\right)$ were determined, respectively, using measuring light $\left[<1 \mu \mathrm{mol}\right.$ (photon) $\left.\mathrm{m}^{-2} \mathrm{~s}^{-1}\right]$ and a 0.8 -s saturating pulse at $6,000 \mu \mathrm{mol}$ (photon) $\mathrm{m}^{-2} \mathrm{~s}^{-1}$. Actinic light of $619 \mu \mathrm{mol}$ (photon) $\mathrm{m}^{-2} \mathrm{~s}^{-1}$ was used. After about $5 \mathrm{~min}$, the steady-state value of fluorescence $\left(\mathrm{F}_{\mathrm{S}}\right)$ was thereafter recorded and a second saturating pulse at 6,000 $\mu$ mol(photon) $\mathrm{m}^{-2} \mathrm{~s}^{-1}$ was imposed to determine $\mathrm{F}_{\mathrm{M}}$ in the light-adapted state $\left(F_{M}\right.$ '). $F_{0}$ ' was basal fluorescence after $5 \mu \mathrm{mol}$ (photon) $\mathrm{m}^{-2} \mathrm{~s}^{-1}$ of far-red irradiation at $720-730 \mathrm{~nm}$ for $4 \mathrm{~s}$, which excites PSI and oxidizes the plastoquinone and $\mathrm{Q}_{\mathrm{A}}$ pools associated with PSII. With these original parameters above, the maximum photochemical quantum yield of PSII $\left(\mathrm{F}_{\mathrm{v}} / \mathrm{F}_{\mathrm{M}}\right)$, efficiency of excitation capture by PSII $\left(\mathrm{F}_{\mathrm{v}}{ }^{\prime} / \mathrm{F}_{\mathrm{M}}{ }^{\prime}\right)$, actual quantum yield of PSII photochemistry $\left(\Phi_{\text {PSII }}\right)$, coefficient of photochemical fluorescence quenching $\left(\mathrm{q}_{\mathrm{p}}\right)$, coefficient of nonphotochemical fluorescence quenching via $\Delta \mathrm{pH}\left(\mathrm{q}_{\mathrm{N}}\right)$, coefficient of nonphotochemical fluorescence quenching via xanthophyll cycle (NPQ), quantum yield of non-light-induced nonphotochemical fluorescence quenching $\left(\Phi_{\mathrm{NO}}\right)$, quantum yield of light-induced $\Delta \mathrm{pH}$ and zeaxanthin-dependent nonphotochemical fluorescence quenching $\left(\Phi_{\mathrm{NPQ}}\right)$ were calculated as defined by previous studies (Kitajima and Butler 1975, Schreiber et al. 1986, Genty et al. 1989, Bilger and Björkman 1990, Kramer et al. 2004).

OJIP transients and analysis of relative parameters: The Chl $a$ fluorescence transients (OJIP-test) were also measured at room temperature $\left(25^{\circ} \mathrm{C}\right)$ with a pulse amplitude modulation fluorometer (PAM-2500, Walz, Germany) after the leaves were dark-adapted for $20 \mathrm{~min}$. Each Chl $a$ fluorescence transient was analyzed according to the JIP-test utilizing original data: (1) the minimum fluorescence intensity [the fluorescence intensity at $20 \mu \mathrm{s}$, $\left.\mathrm{F}_{0}\right]$; (2) the maximum fluorescence intensity $\left(\mathrm{F}_{\mathrm{M}}\right) ;(3)$ the fluorescence intensity at $2 \mathrm{~ms}\left(\mathrm{~J}-\mathrm{step}, \mathrm{F}_{\mathrm{J}}\right)$ and $30 \mathrm{~ms}$ (I-step, $\mathrm{F}_{\mathrm{I}}$ ) (Stirbet and Govindjee 2011).

The relative variable fluorescence intensity at J-step $\left(\mathrm{V}_{\mathrm{J}}\right)$ and I-step $\left(\mathrm{V}_{\mathrm{I}}\right)$ were calculated as: $\mathrm{V}_{\mathrm{t}}=\left(\mathrm{F}_{\mathrm{t}}-\mathrm{F}_{0}\right) /$ $\left(\mathrm{F}_{\mathrm{M}}-\mathrm{F}_{0}\right)$. In JIP-test, $\mathrm{ET}_{0} / \mathrm{TR}_{0}=1-\mathrm{V}_{\mathrm{J}}$, reflecting the probability that a PSII trapped electron is transferred from $\mathrm{Q}_{\mathrm{A}}$ to $\mathrm{Q}_{\mathrm{B}} ; \mathrm{RE}_{0} / \mathrm{TR}_{0}=1-\mathrm{V}_{\mathrm{I}}$, reflecting the probability a PSII trapped electron is transferred until PSI acceptors; and $\mathrm{RE}_{0} / \mathrm{ET}_{0}=\left(1-\mathrm{V}_{\mathrm{I}}\right) /\left(1-\mathrm{V}_{\mathrm{J}}\right)$, reflecting the probability an electron from $\mathrm{Q}_{\mathrm{B}}$ is transferred until PSI acceptors. In addition, in the JIP-test, $\mathrm{F}_{\mathrm{v}} / \mathrm{F}_{\mathrm{M}} \times \mathrm{ET}_{0} / \mathrm{TR}_{0}, \mathrm{~F}_{\mathrm{v}} / \mathrm{F}_{\mathrm{M}} \times$ $\mathrm{RE}_{0} / \mathrm{TR}_{0}, \mathrm{~F}_{\mathrm{v}} / \mathrm{F}_{\mathrm{M}} \times \mathrm{RE}_{0} / \mathrm{ET}_{0}$ reflect the quantum yield of the electron transport flux from $\mathrm{Q}_{\mathrm{A}}$ to $\mathrm{Q}_{\mathrm{B}}$, quantum yield of the electron transport flux until the PSI electron acceptors, quantum yield of the electron transport flux from $\mathrm{Q}_{B}$ until PSI acceptors, respectively.

The parameters reflecting absorbed photon flux were calculated as follows: $\mathrm{ABS} / \mathrm{RC}=\left(\mathrm{M}_{0} / \mathrm{V}_{\mathrm{J}}\right) \times\left[1 /\left(\mathrm{F}_{\mathrm{v}} / \mathrm{F}_{\mathrm{M}}\right)\right]$, quantifying average absorbed photon flux per PSII reaction center $(\mathrm{RC}) ; \mathrm{ABS} / \mathrm{CS}_{0}=\mathrm{F}_{0}$, quantifying absorbed photon flux per cross section (CS). The parameters that reflect trapped exciton flux were calculated as follows: $\mathrm{TR}_{0} / \mathrm{RC}=\mathrm{M}_{0} / \mathrm{V}_{\mathrm{J}}$, quantifying maximum trapped exciton flux per PSII RC; $\mathrm{TR}_{0} / \mathrm{CS}_{0}=\mathrm{F}_{\mathrm{v}} / \mathrm{F}_{\mathrm{M}} \times \mathrm{F}_{0}$, quantifying maximum trapped exciton flux per CS. The parameters that reflect energy dissipation were calculated as follows: $\mathrm{DI}_{0} / \mathrm{RC}=\mathrm{ABS} / \mathrm{RC}-\mathrm{TR}_{0} / \mathrm{RC}$, quantifying dissipated energy flux per active PSII RC; $\mathrm{DI}_{0} / \mathrm{CS}_{0}(\mathrm{t}=20 \mu \mathrm{s})=\mathrm{ABS} / \mathrm{CS}_{0}-$ $\mathrm{TR}_{0} / \mathrm{CS}_{0}$, quantifying dissipated energy flux per $\mathrm{CS}$.

$\mathrm{H}_{2} \mathrm{O}_{2}$ and $\mathrm{O}_{2}{ }^{\cdot-}$ contents were determined according to Chen (2013). Fresh leaf powder of $0.1 \mathrm{~g}$ was homogenized with $1.8 \mathrm{ml}$ of $5 \%(\mathrm{w} / \mathrm{v})$ trichloroacetic acid and then centrifuged at $16,000 \times \mathrm{g}$ for $10 \mathrm{~min}$. The supernatant was neutralized to $\mathrm{pH} 7.5$ with $17 \mathrm{M} \mathrm{NH}_{4} \mathrm{OH}$, and used for assay immediately.

For $\mathrm{O}_{2}{ }^{--}$assay, the extract was divided into two aliquots of $100 \mu$ l. Superoxide dismutase [SOD, $50 \mathrm{U}, 10,000 \mathrm{U}$ $\mathrm{mg}^{-1}$ (protein), Sigma, USA] was added to one aliquot (blank). Both the blank and the other aliquot without SOD were added to $0.9 \mathrm{ml}$ with $50 \mathrm{mM}$ Tris- $\mathrm{HCl}(\mathrm{pH} 7.5)$, and then kept at room temperature for $10 \mathrm{~min}$, before adding $100 \mu \mathrm{l}$ of $5 \mathrm{mM}$ 2,3-bis(2-methoxy-4-nitro-5-sulfophenyl)-2H-tetrazolium-5-carboxanilide inner salt. The reaction mixture was incubated at room temperature for $10 \mathrm{~min}$, and then the absorbance at $470 \mathrm{~nm}$ was monitored. The difference on absorbance between the blank and the other aliquot was used to calculate the concentration of $\mathrm{O}_{2}{ }^{-}$ using an extinction coefficient of $21.6 \mathrm{mM}^{-1} \mathrm{~cm}^{-1}$.

For $\mathrm{H}_{2} \mathrm{O}_{2}$ assay, the extract was divided into two aliquots of $100 \mu$ l. Catalase [CAT, $20 \mathrm{U}, 20,000 \mathrm{U}$ $\mathrm{mg}^{-1}$ (protein), Sigma, USA] was added to one aliquot (blank). Both the blank and the other aliquot without CAT were added to $0.5 \mathrm{ml}$ with $50 \mathrm{mM}$ Tris- $\mathrm{HCl}(\mathrm{pH} \mathrm{7.5)}$ buffer, and then kept at room temperature for $10 \mathrm{~min}$, following the addition of $0.5 \mathrm{ml}$ of colorimetric reagent. The colorimetric reagent was made daily by mixing $1: 1$ (v/v) $0.3 \mathrm{mM}$ potassium titanium oxalate and $0.3 \mathrm{mM}$ 4-(2-pyridylazo)resorcinol monosodium salt. The assay mixture was incubated at room temperature for $15 \mathrm{~min}$ and then the absorbance at $508 \mathrm{~nm}$ was monitored ( $U V-2800$, Unic, Shanghai, China). The difference on absorbance between the blank and the other aliquot was used to calculate the concentration of $\mathrm{H}_{2} \mathrm{O}_{2}$ using an extinction coefficient of $39.4 \mathrm{mM}^{-1} \mathrm{~cm}^{-1}$.

Antioxidant enzymes activities: Fresh tissue samples $(0.1 \mathrm{~g}$ each) were homogenized with $1.8 \mathrm{ml}$ of $100 \mathrm{mM}$ phosphate buffer saline PBS (pH 7.0) containing $5 \%(\mathrm{w} / \mathrm{v})$ polyvinylpyrrolidone, $1.0 \mathrm{mM}$ EDTA and $1 \%$ Triton $X-100$. The homogenates were centrifuged at $13,000 \times g$ for $20 \mathrm{~min}$ at $4^{\circ} \mathrm{C}$ and the supernatants were used for enzyme assays. All enzyme activities were calculated on fresh mass basis. 
CAT (EC 1.11.1.6) activity was determined by monitoring the decrease in absorbance at $240 \mathrm{~nm}$ due to decomposition of $\mathrm{H}_{2} \mathrm{O}_{2}$ (Díaz-Vivancos et al. 2008). The $1.0 \mathrm{ml}$ of reaction mixture contained $50 \mathrm{mM}$ PBS ( $\mathrm{pH} 7.0$ ), $10 \mathrm{mM} \mathrm{H}_{2} \mathrm{O}_{2}$, and $20 \mu \mathrm{l}$ of enzyme extract. This reaction was initiated by adding $\mathrm{H}_{2} \mathrm{O}_{2}$. One CAT unit was defined as the amount of enzyme necessary to decompose $1 \mathrm{mM}\left(\mathrm{H}_{2} \mathrm{O}_{2}\right) \mathrm{min}^{-1}$ under the above-mentioned assay conditions. The specific CAT activity was expressed as $\mathrm{U} \mathrm{g}^{-1}(\mathrm{FM}) \mathrm{min}^{-1}$.

Peroxidase (POD, EC 1.11.1.7) activity was measured by the increase in absorbance at $470 \mathrm{~nm}$ due to guaiacol oxidation (Nickel and Cunningham 1969). The reaction mixture of $1.0 \mathrm{ml}$ contained $10 \mathrm{mM}$ guaiacol, $10 \mathrm{mM}$ $\mathrm{H}_{2} \mathrm{O}_{2}$, and $20 \mu \mathrm{l}$ of enzyme extract. The reaction was started by adding $\mathrm{H}_{2} \mathrm{O}_{2}$. One unit of POD activity was defined as the amount of the enzyme causing a change in absorbance at $470 \mathrm{~nm}$ of 0.01 per min. The specific POD activity $\left[\mathrm{U} \mathrm{g}^{-1}(\mathrm{FM}) \mathrm{min}^{-1}\right]=\left(\triangle \mathrm{A}_{470} \times \mathrm{V}\right) /\left(\mathrm{M} \times \mathrm{V}_{\mathrm{s}} \times 0.01 \times\right.$ $\mathrm{t}$ ), in expressions, $\triangle \mathrm{A}_{470}$ was the change of $\mathrm{A}_{470}$ during every minute; $\mathrm{V}$ was total volume of crude enzyme solution; $\mathrm{V}_{\mathrm{s}}$ was volume of crude enzyme used in the determination; $M$ was mass of fresh materials; $t$ was reaction time in $\mathrm{min}$.

SOD (EC 1.15.1.1) activity was assayed by monitoring the inhibition of the photochemical reduction of nitroblue tetrazolium (NBT), according to the methods of Rao and Sresty (2000). The $1.0 \mathrm{ml}$ of reaction mixture contained $50 \mathrm{mM}$ PBS (pH 7.8), $6.5 \mathrm{mM}$ methionine, $50 \mu \mathrm{M}$ NBT, $10 \mu \mathrm{M}$ EDTA, $20 \mu \mathrm{M}$ riboflavin, and $20 \mu \mathrm{l}$ of enzyme extract. A reaction mixture lacking enzyme served as the control. All mixtures were stirred under darkness in small glass test tubes, and then irradiated for $5 \mathrm{~min}$ by fluorescent lamps $\left[160 \mu \mathrm{mol}\right.$ (photon) $\left.\mathrm{m}^{-2} \mathrm{~s}^{-1}\right]$ before measured at $560 \mathrm{~nm}$. The mixture that lacked enzyme was used to zero the absorbance at $560 \mathrm{~nm}(U V-2800$, Unic, Shanghai, China). One unit of SOD was defined as the amount of enzyme that produced $50 \%$ inhibition of NBT reduction under assay conditions. The specific SOD activity was expressed as $\mathrm{U} \mathrm{g}^{-1}(\mathrm{FM})$.

Ascorbate peroxidase (APX, EC 1.11.1.11) activity was evaluated by monitoring the decrease in absorbance at 290 $\mathrm{nm}$ as ascorbate was oxidized (Nakano and Asada 1981). The $1.0 \mathrm{ml}$ of reaction mixture contained $50 \mathrm{mM}$ PBS (pH 7.6), $0.1 \mathrm{mM}$ EDTA, $0.5 \mathrm{mM}$ reduced ascorbate (AsA), $1 \mathrm{mM} \mathrm{H}_{2} \mathrm{O}_{2}$, and $20 \mu \mathrm{l}$ of enzyme extract. The reaction was initiated by adding $\mathrm{H}_{2} \mathrm{O}_{2}$. One unit of APX activity was defined as the amount of the enzyme causing a change in $1.0 \mu \mathrm{mol}$ AsA was oxidized per min. The specific APX activity $\left[\mathrm{U} \mathrm{g}^{-1}(\mathrm{FM}) \mathrm{min}^{-1}\right]=\left(\triangle \mathrm{A}_{290} \times \mathrm{V}\right) /(2.8 \times \mathrm{M} \times$ $\mathrm{V} \times \mathrm{t}$ ), in expressions, $\triangle \mathrm{A}_{290}$ was the change of $\mathrm{A}_{290}$ during $30 \mathrm{~s}$; $\mathrm{V}$ was total volume of crude enzyme solution; $2.8 \mathrm{mM}^{-1} \mathrm{~cm}^{-1}$ was an extinction coefficient; $M$ was mass of fresh materials; $t$ was reaction time, $0.5 \mathrm{~min}$.

Dehydroascorbate reductase (DHAR, EC 1.8.5.1) activity was determined by monitoring the increase in absorbance at $265 \mathrm{~nm}$ due to AsA formation (Nakano and Asada 1981). The $1.0 \mathrm{ml}$ of reaction mixture contained $50 \mathrm{mM}$ potassium phosphate buffer ( $\mathrm{pH} 7.6), 2.5 \mathrm{mM}$ reduced glutathione (GSH), $0.1 \mathrm{mM}$ EDTA, $0.2 \mathrm{mM}$ dehydroascorbate (DHA), and $20 \mu \mathrm{l}$ of enzyme extract. The reaction was initiated by adding DHA. One unit of DHAR activity was defined as the amount of the enzyme causing a change in $1.0 \mu \mathrm{mol}$ AsA formation per min at absorbance at $265 \mathrm{~nm}$. The specific DHAR activity $\left[\mathrm{U} \mathrm{g}^{-1}(\mathrm{FM}) \min ^{-1}\right]=\left(\triangle \mathrm{A}_{265} \times \mathrm{V}\right) /\left(\mathrm{M} \times \mathrm{V}_{\mathrm{s}} \times 5.42 \times \mathrm{t}\right)$, in expressions, $\triangle \mathrm{A}_{265}$ was the change of $\mathrm{A}_{265}$ during every minute; $\mathrm{V}$ was total volume of crude enzyme solution; $\mathrm{V}_{\mathrm{s}}$ was volume of crude enzyme used in the determination; $M$ was mass of fresh materials; $5.42 \mathrm{mM}^{-1} \mathrm{~cm}^{-1}$ was an extinction coefficient; $\mathrm{t}$ was reaction time, $3.0 \mathrm{~min}$.

Monodehydroascorbate reductase (MDHAR, EC 1.6.5.4) activity was assayed by monitoring the decrease in absorbance at $340 \mathrm{~nm}$ due to NADH oxidation (Nakano and Asada 1981). The $1.0 \mathrm{ml}$ of reaction mixture contained $50 \mathrm{mM}$ PBS ( $\mathrm{pH} 7.6$ ), $2.5 \mathrm{mM}$ AsA, $0.1 \mathrm{mM}$ EDTA, $0.1 \mathrm{mM}$ NADH, 0.5 units of AsA oxidase (EC 1.10.3.3), and $20 \mu \mathrm{l}$ of enzyme extract. The reaction was initiated by adding AsA oxidase. One unit of MDHAR activity was defined as the amount of the enzyme causing a change in $1.0 \mu$ mol NADH oxidation per min. The specific MDHAR activity was expressed as $\mathrm{U} \mathrm{g}^{-1}(\mathrm{FM}) \mathrm{min}^{-1}$.

Glutathione reductase (GR, EC 1.6.4.2) activity was measured by monitoring the decrease in absorbance at $340 \mathrm{~nm}$ due to NADPH oxidation (Zhang and Kirkham 1996). The $1.0 \mathrm{ml}$ of reaction mixture contained $50 \mathrm{mM}$ PBS (pH 7.0), 0.2 mM EDTA, 0.1 mM NADPH, $0.25 \mathrm{mM}$ oxidized glutathione (GSSG), and $100 \mu \mathrm{l}$ of enzyme extract. The reaction was initiated by adding NADPH. The GR activity was calculated by measuring the change in absorbance at $340 \mathrm{~nm}$ for GSSG-dependent oxidation of NAPDH. One unit of GR activity was defined as the amount of the enzyme causing a change in $1.0 \mu \mathrm{mol}$ NADPH oxidation per min. The specific GR activity $\left[\mathrm{U} \mathrm{g}^{-1}(\mathrm{FM}) \min ^{-1}\right]=\left(\triangle \mathrm{A}_{340} \times \mathrm{V}\right) /\left(\mathrm{M} \times \mathrm{V}_{\mathrm{s}} \times 6.22 \times \mathrm{t}\right)$, in expressions, $\triangle \mathrm{A}_{340}$ was the change of $\mathrm{A}_{340}$ during every minute; $\mathrm{V}$ was total volume of crude enzyme solution; $\mathrm{V}_{\mathrm{s}}$ was volume of crude enzyme used in the determination; $M$ was mass of fresh materials; $6.22 \mathrm{mM}^{-1} \mathrm{~cm}^{-1}$ was an extinction coefficient; $\mathrm{t}$ was reaction time, $3.5 \mathrm{~min}$.

Statistical analysis: All statistical analysis were conducted with the SPSS software (Version 19, SPSS Inc., USA). Analysis of variance (ANOVA) were used to evaluate the effects of treatment. Significant differences between plants with different treatment were calculated at $p<0.05$ level, using Duncan's tests. Values were presented as the means of ten replicates \pm standard error (SE). Figures were finished with the Origin Pro software (Version 7.5, OriginLab Inc., USA). 


\section{Results}

Ge accumulation: Compared with the control, exogenous $\mathrm{GeO}_{2}$ application significantly increased endogenous Ge contents of both inorganic and organic germanium form in leaves (Table 1). Specifically, inorganic germanium content in leaves treated with 1.0, 2.0, 5.0, and $10.0 \mathrm{mg}\left(\mathrm{GeO}_{2}\right) \mathrm{L}^{-1}$ was $2.6,11.2,14.2$, and 21.9 times higher than the control, respectively; organic Ge content in leaves was $30.7,44.8,61.8$, and 102.8 times higher than the control, respectively. Although the exogenous Ge was applied in its inorganic form $\left(\mathrm{GeO}_{2}\right)$, in apple leaves, organic Ge content was significantly higher than that of inorganic form.

Change of $\mathrm{Chl}$ content in apple leaves: Chl $a$ content increased with 1.0, 2.0, and $5.0 \mathrm{mg}\left(\mathrm{GeO}_{2}\right) \mathrm{L}^{-1}$ treatment compared with control, but there was no remarkable difference between $10.0 \mathrm{mg} \mathrm{L}^{-1}$ and control (Table 2). The total $\mathrm{Chl}(a+b)$ content changed similarly as $\mathrm{Chl} a$. Chl $b$ content did not increase as much as $\mathrm{Chl} a$, although its content with $5.0 \mathrm{mg} \mathrm{L}^{-1}$ was significantly higher than that with 1.0 and $10.0 \mathrm{mg}\left(\mathrm{GeO}_{2}\right) \mathrm{L}^{-1}$ treatments and control. For Chl $a / b$, only the value after $10.0 \mathrm{mg} \mathrm{L}^{-1}$ treatment was significantly lower than others.

Table 1. Contents of total Ge, inorganic Ge, and organic Ge in apple leaves with treatments of different $\mathrm{GeO}_{2}$ concentrations. Each value is the mean \pm standard error of ten independent measurements. Means $\pm \operatorname{SE}(n=6)$. Different lowercase letters indicate significant differences between treatments $(P<0.05)$.

\begin{tabular}{lclc}
\hline $\begin{array}{l}\mathrm{GeO}_{2} \\
{\left[\mathrm{mg} \mathrm{L}^{-1}\right]}\end{array}$ & $\begin{array}{l}\text { Total Ge } \\
{\left[\mathrm{mg} \mathrm{kg}^{-1}(\mathrm{DM})\right]}\end{array}$ & $\begin{array}{l}\text { Inorganic Ge } \\
{\left[\mathrm{mg} \mathrm{kg}^{-1}(\mathrm{DM})\right]}\end{array}$ & $\begin{array}{l}\text { Organic Ge } \\
{\left[\mathrm{mg} \mathrm{kg}^{-1}(\mathrm{DM})\right]}\end{array}$ \\
\hline 0 & $1.53 \pm 0.22^{\mathrm{e}^{*}}$ & $0.19 \pm 0.06^{\mathrm{d}}$ & $1.34 \pm 0.18^{\mathrm{e}}$ \\
1.0 & $43.23 \pm 4.14^{\mathrm{d}}$ & $0.70 \pm 0.19^{\mathrm{c}}$ & $42.53 \pm 3.95^{\mathrm{d}}$ \\
2.0 & $63.70 \pm 3.90^{\mathrm{c}}$ & $2.32 \pm 0.22^{\mathrm{b}}$ & $61.39 \pm 3.99^{\mathrm{c}}$ \\
5.0 & $87.06 \pm 16.28^{\mathrm{b}}$ & $2.88 \pm 0.75^{\mathrm{b}}$ & $84.18 \pm 17.03^{\mathrm{b}}$ \\
10.0 & $143.41 \pm 10.18^{\mathrm{a}}$ & $4.35 \pm 0.35^{\mathrm{a}}$ & $139.06 \pm 10.52^{\mathrm{a}}$ \\
\hline
\end{tabular}

Modulated Chl fluorescence parameters: In apple leaves with $1.0,2.0$ and $5.0 \mathrm{mg}\left(\mathrm{GeO}_{2}\right) \mathrm{L}^{-1}$, the $\mathrm{Chl}$ fluorescence parameters, such as $\mathrm{F}_{\mathrm{v}} / \mathrm{F}_{\mathrm{M}}, \mathrm{F}_{\mathrm{v}}{ }^{\prime} / \mathrm{F}_{\mathrm{M}^{\prime}}, \mathrm{q}_{\mathrm{P}}, \mathrm{q}_{\mathrm{L}}$, and
$\Phi_{\text {PSII }}$, increased significantly under both 800 and 1, 600 $\mu$ mol(photon) $\mathrm{m}^{-2} \mathrm{~s}^{-1}$ (Table 3). These five parameters declined after $10.0 \mathrm{mg}\left(\mathrm{GeO}_{2}\right) \mathrm{L}^{-1}$ treatment. On the other hand, the value of NPQ and $\mathrm{q}_{\mathrm{N}}$, both quantifying the energy dissipation, declined in apple leaves with 1.0, 2.0, and $5.0 \mathrm{mg}\left(\mathrm{GeO}_{2}\right) \mathrm{L}^{-1}$ and rose at the concentration of $10.0 \mathrm{mg} \mathrm{L}^{-1}$. Meanwhile, the change of NPQ and $\mathrm{q}_{\mathrm{N}}$ affected the value of $\Phi_{\mathrm{NPQ}}$, but not $\Phi_{\mathrm{NO}}$. $\Phi_{\mathrm{NPQ}}$ decreased with 1.0, 2.0, and $5.0 \mathrm{mg}\left(\mathrm{GeO}_{2}\right) \mathrm{L}^{-1}$ and increased in $10.0 \mathrm{mg}\left(\mathrm{GeO}_{2}\right) \mathrm{L}^{-1}$, while $\Phi_{\mathrm{NO}}$ was maintained stable compared with control.

OJIP transients and relative parameters: Clearly, in Chl fluorescence transient, exogenous $\mathrm{GeO}_{2}$ changed the momentary maximum fluorescence intensity of J-step and I-step (Fig. 1). The parameters including $1-\mathrm{V}_{\mathrm{J}}, 1-\mathrm{V}_{\mathrm{I}}$, $\left(1-\mathrm{V}_{\mathrm{I}}\right) /\left(1-\mathrm{V}_{\mathrm{J}}\right), \mathrm{F}_{\mathrm{v}} / \mathrm{F}_{\mathrm{M}} \times\left(1-\mathrm{V}_{\mathrm{J}}\right), \mathrm{F}_{\mathrm{v}} / \mathrm{F}_{\mathrm{M}} \times\left(1-\mathrm{V}_{\mathrm{I}}\right)$, and $\mathrm{F}_{\mathrm{v}} / \mathrm{F}_{\mathrm{M}} \times\left(1-\mathrm{V}_{\mathrm{I}}\right) /\left(1-\mathrm{V}_{\mathrm{J}}\right)$ all showed a rising trend along with the increase of $\mathrm{GeO}_{2}$ concentration and reached a peak when it was $5.0 \mathrm{mg} \mathrm{L}^{-1}$, then all declined at $10.0 \mathrm{mg}$ $\mathrm{L}^{-1}$ (Fig. 2). A significant difference in $1-\mathrm{V}_{\mathrm{J}}$ between 800 and 1,600 $\mu$ mol(photon) $\mathrm{m}^{-2} \mathrm{~s}^{-1}$ was observed as well as in $\mathrm{F}_{\mathrm{v}} / \mathrm{F}_{\mathrm{M}} \times\left(1-\mathrm{V}_{\mathrm{J}}\right)$, while other four parameters with same $\mathrm{GeO}_{2}$ treatment were almost equal under the two light intensities.

We also determined partitioning of absorbed light energy via photochemical reaction and thermal dissipation. The change of parameters including $\mathrm{ABS} / \mathrm{RC}$, $\mathrm{ABS} / \mathrm{CS}_{0}, \quad \mathrm{TR}_{0} / \mathrm{RC}, \quad \mathrm{TR}_{0} / \mathrm{CS}_{0}, \mathrm{DI}_{0} / \mathrm{RC}, \quad \mathrm{DI}_{0} / \mathrm{CS}_{0}$ were shown in Fig. 3. The light absorption per residue active $\mathrm{RC}$ $(\mathrm{ABS} / \mathrm{RC})$ and per $\mathrm{CS}\left(\mathrm{ABS} / \mathrm{CS}_{0}\right)$ in control and at 10.0 $\mathrm{mg} \mathrm{L}^{-1}$ were higher than that at $1.0,2.0$, and $5.0 \mathrm{mg}\left(\mathrm{GeO}_{2}\right)$ $\mathrm{L}^{-1}$ (Fig. 3A,D). Moreover, the values of $\mathrm{ABS} / \mathrm{RC}$ and $\mathrm{ABS} / \mathrm{CS}_{0}$ under $1,600 \mu \mathrm{mol}$ (photon) $\mathrm{m}^{-2} \mathrm{~s}^{-1}$ were both lower than that under $800 \mu \mathrm{mol}$ (photon) $\mathrm{m}^{-2} \mathrm{~s}^{-1}$. TR 0 RC and $\mathrm{TR}_{0} / \mathrm{CS}_{0}$ did not change remarkably with different concentrations of exogenous $\mathrm{GeO}_{2}$ solutions and different light intensities (Fig. $3 B, E$ ). $\mathrm{DI}_{0} / \mathrm{RC}$ and $\mathrm{DI}_{0} / \mathrm{CS}_{0}$, dissipated energy flux per PSII RC and CS, decreased at 1.0, 2.0, and $5.0 \mathrm{mg}\left(\mathrm{GeO}_{2}\right) \mathrm{L}^{-1}$ (Fig. 3C,F), meaning lesser dissipation of excess excitation energy in these chloroplasts.

Table 2. Effect of different $\mathrm{GeO}_{2}$ concentrations on chlorophyll $(\mathrm{Chl})$ content in apple leaves. Means $\pm \mathrm{SE}(n=6)$. Different lowercase letters indicate significant differences between treatments $(P<0.05)$.

\begin{tabular}{lllll}
\hline $\mathrm{GeO}_{2}\left[\mathrm{mg} \mathrm{L}^{-1}\right]$ & $\mathrm{Chl}(a+b)\left[\mathrm{mg} \mathrm{g}^{-1}\right]$ & $\mathrm{Chl} a\left[\mathrm{mg} \mathrm{g}^{-1}\right]$ & $\mathrm{Chl} b\left[\mathrm{mg} \mathrm{g}^{-1}\right]$ & $\mathrm{Chl} a / b$ \\
\hline 0 & $2.21 \pm 0.07^{\mathrm{d}}$ & $1.64 \pm 0.05^{\mathrm{d}}$ & $0.57 \pm 0.01^{\mathrm{c}}$ & $2.85 \pm 0.05^{\mathrm{ab}}$ \\
1.0 & $2.38 \pm 0.03^{\mathrm{c}}$ & $1.76 \pm 0.03^{\mathrm{c}}$ & $0.62 \pm 0.01^{\mathrm{b}}$ & $2.86 \pm 0.03^{\mathrm{a}}$ \\
2.0 & $2.48 \pm 0.05^{\mathrm{b}}$ & $1.84 \pm 0.02^{\mathrm{b}}$ & $0.64 \pm 0.02^{\mathrm{ab}}$ & $2.87 \pm 0.04^{\mathrm{a}}$ \\
5.0 & $2.62 \pm 0.04^{\mathrm{a}}$ & $1.94 \pm 0.03^{\mathrm{a}}$ & $0.68 \pm 0.02^{\mathrm{a}}$ & $2.86 \pm 0.02^{\mathrm{a}}$ \\
10.0 & $2.27 \pm 0.03^{\mathrm{d}}$ & $1.67 \pm 0.04^{\mathrm{d}}$ & $0.60 \pm 0.02^{\mathrm{bc}}$ & $2.76 \pm 0.04^{\mathrm{b}}$ \\
\hline
\end{tabular}


$\mathrm{H}_{2} \mathrm{O}_{2}$ and $\mathrm{O}_{2}{ }^{-}$- contents were similarly affected by $\mathrm{GeO}_{2}$ application in apple leaves (Fig. 4). Under two light conditions, $\mathrm{H}_{2} \mathrm{O}_{2}$ contents in the leaves significantly decreased with $1.0,2.0$, and $5.0 \mathrm{mg}\left(\mathrm{GeO}_{2}\right) \mathrm{L}^{-1}$. For $\mathrm{O}_{2}{ }^{--}$, its contents descended with above three concentrated $\mathrm{GeO}_{2}$ solutions under $1,600 \mu \mathrm{mol}\left(\right.$ photon) $\mathrm{m}^{-2} \mathrm{~s}^{-1}$, but under 800 $\mu$ mol(photon) $\mathrm{m}^{-2} \mathrm{~s}^{-1}$, it only continually descended significantly with 1.0 and $2.0 \mathrm{mg}\left(\mathrm{GeO}_{2}\right) \mathrm{L}^{-1}$ and did not show significant difference between 2.0 and $5.0 \mathrm{mg}\left(\mathrm{GeO}_{2}\right)$ $\mathrm{L}^{-1}$. However, the accumulation of $\mathrm{H}_{2} \mathrm{O}_{2}$ and $\mathrm{O}_{2}{ }^{-}$significantly increased by application of $10.0 \mathrm{mg}\left(\mathrm{GeO}_{2}\right) \mathrm{L}^{-1}$. And furthermore, apple leaves generated more $\mathrm{H}_{2} \mathrm{O}_{2}$ and $\mathrm{O}_{2}{ }^{-}$ under $1,600 \mu$ mol(photon) $\mathrm{m}^{-2} \mathrm{~s}^{-1}$ than that under 800 $\mu \operatorname{mol}\left(\right.$ photon) $\mathrm{m}^{-2} \mathrm{~s}^{-1}$. These results indicate Ge could decrease the accumulation of ROS in the apple leaves and alleviate ROS-induced membrane damage.

Activities of CAT, POD and SOD were enhanced in apple leaves along with the rise of the exogenous $\mathrm{GeO}_{2}$ concentration and reached a peak at the concentration of $5.0 \mathrm{mg}\left(\mathrm{GeO}_{2}\right) \mathrm{L}^{-1}$ and then the activities of these three enzymes declined after the treatment by $10.0 \mathrm{mg}\left(\mathrm{GeO}_{2}\right) \mathrm{L}^{-1}$ (Fig. 5). For the two light intensities, 1,600 $\mu$ mol(photon) $\mathrm{m}^{-2} \mathrm{~s}^{-1}$ stimulated the activities of CAT and POD noticeably compared to those under $800 \mu$ mol(photon) $\mathrm{m}^{-2} \mathrm{~s}^{-1}$. Similar difference was not found for the activity of SOD with $\mathrm{GeO}_{2}$ application.

Activities of ascorbate-glutathione cycle enzymes: Exogenous $\mathrm{GeO}_{2}$ application significantly changed the activities of antioxidant enzymes including MDHAR, DHAR, APX, and GR under both light intensities (Fig. 6). Among them, MDHAR and DHAR were influenced by exogenous $\mathrm{GeO}_{2}$ in a similar way. Activities of the two enzymes increased with the increasing concentration of $\mathrm{GeO}_{2}$ solution compared with the control and the rising trend slowed down when the concentration was above $5.0 \mathrm{mg} \mathrm{L}^{-1}$. The activities of APX and GR in apple leaves with $\mathrm{GeO}_{2}$ treatment were enhanced along with the increase of exogenous $\mathrm{GeO}_{2}$ concentration, but started to decline when the concentration was above $5.0 \mathrm{mg} \mathrm{L}^{-1}$. In addition, activities of four enzymes of MDHAR, DHAR, APX, and GR under 1,600 $\mu$ mol(photon) $\mathrm{m}^{-2} \mathrm{~s}^{-1}$ were higher than that under $800 \mu$ mol(photon) $\mathrm{m}^{-2} \mathrm{~s}^{-1}$ after $\mathrm{GeO}_{2}$ treatment. 


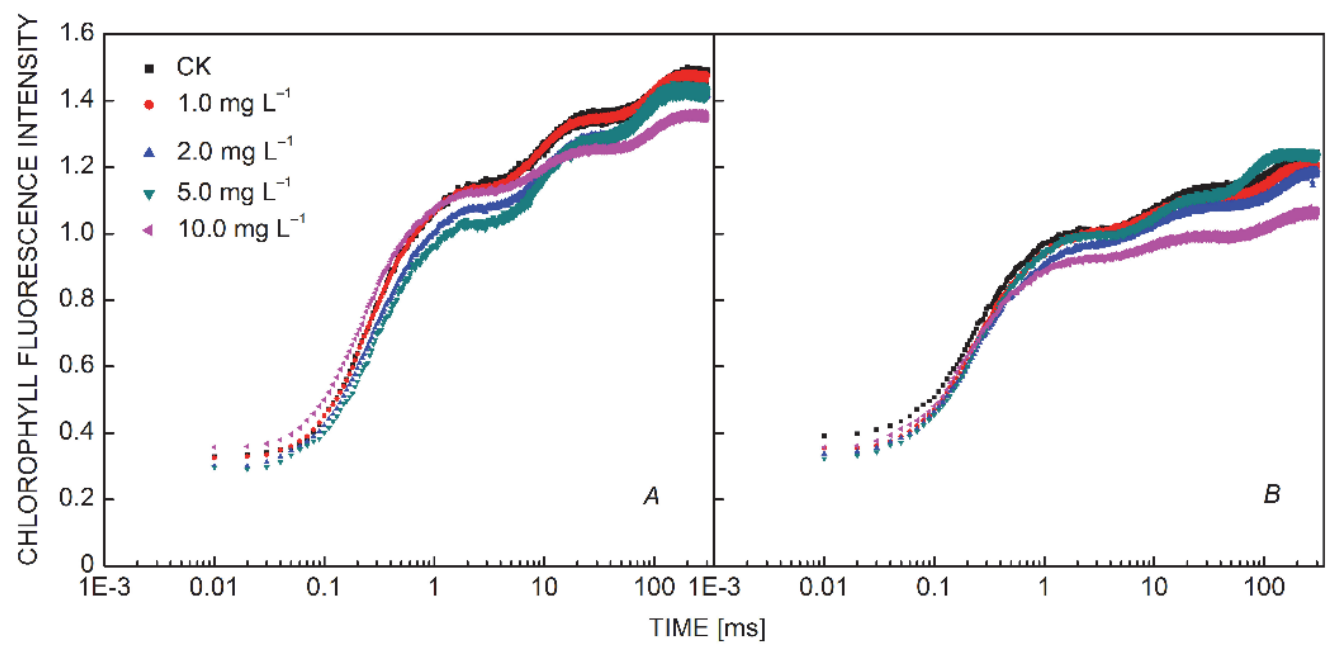

Fig. 1. Effect of different $\mathrm{GeO}_{2}$ concentrations on chlorophyll fluorescence intensity in JIP-test under $800 \mu$ mol(photon) $\mathrm{m}^{-2} \mathrm{~s}^{-1}(A)$ and $1,600 \mu \mathrm{mol}($ photon $) \mathrm{m}^{-2} \mathrm{~s}^{-1}(B)$ in apple leaves.

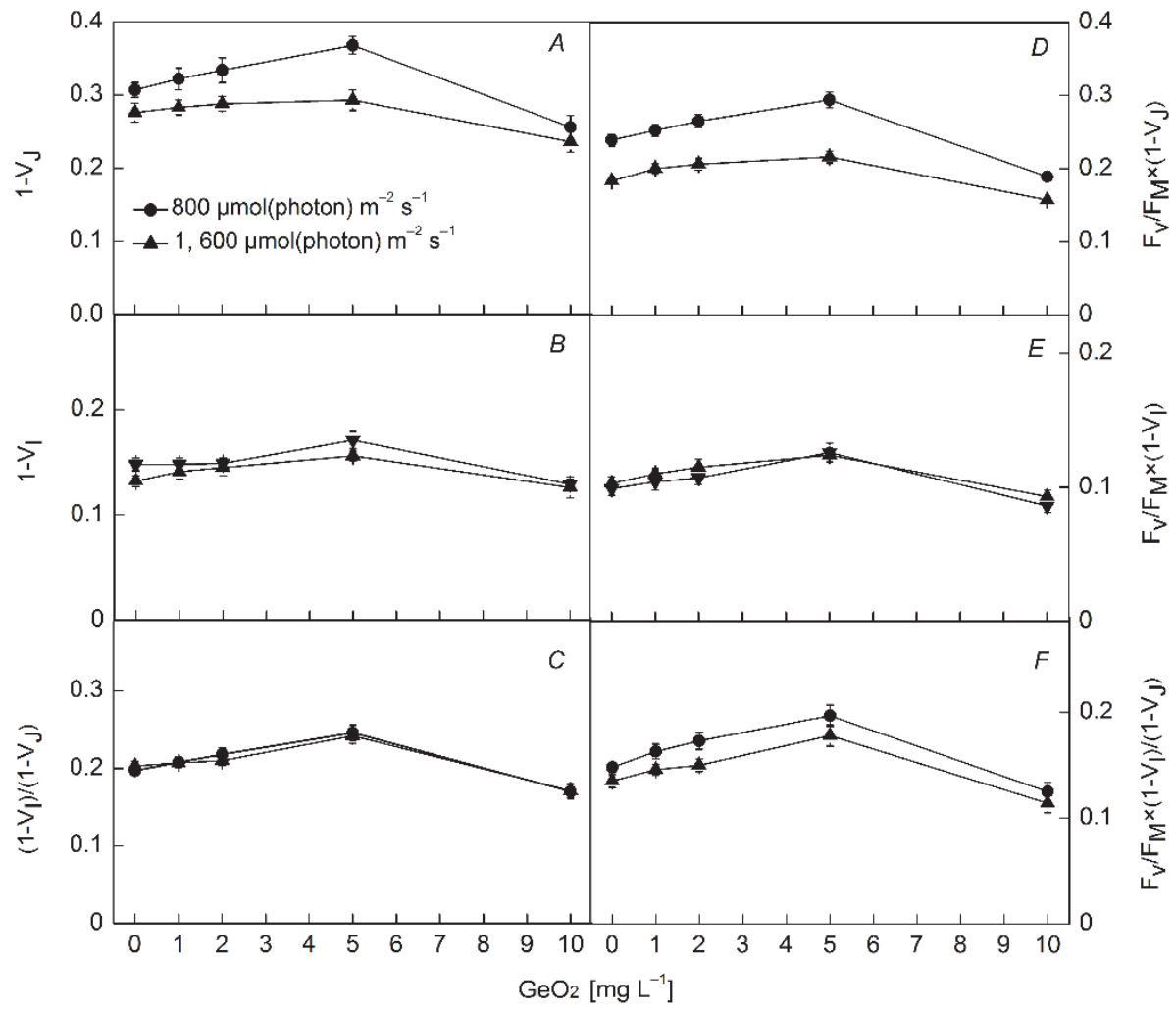

Fig. 2 Change in values of $(A) 1-\mathrm{V}_{\mathrm{J}},(B) 1-\mathrm{V}_{\mathrm{I}},(C)\left(1-\mathrm{V}_{\mathrm{I}}\right) /\left(1-\mathrm{V}_{\mathrm{J}}\right),(D) \mathrm{F}_{\mathrm{V}} / \mathrm{F}_{\mathrm{M}} \times\left(1-\mathrm{V}_{\mathrm{J}}\right),(E) \mathrm{F}_{\mathrm{v}} / \mathrm{F}_{\mathrm{M}} \times\left(1-\mathrm{V}_{\mathrm{I}}\right)$, and $(F) \mathrm{F}_{\mathrm{v}} / \mathrm{F}_{\mathrm{M}} \times$ $\left(1-\mathrm{V}_{\mathrm{I}}\right) /\left(1-\mathrm{V}_{\mathrm{J}}\right)$ in apple leaves under 800 and $1,600 \mu \mathrm{mol}($ photon $) \mathrm{m}^{-2} \mathrm{~s}^{-1}$ for $4 \mathrm{~h}$ with different $\mathrm{GeO}_{2}$ concentrations. 


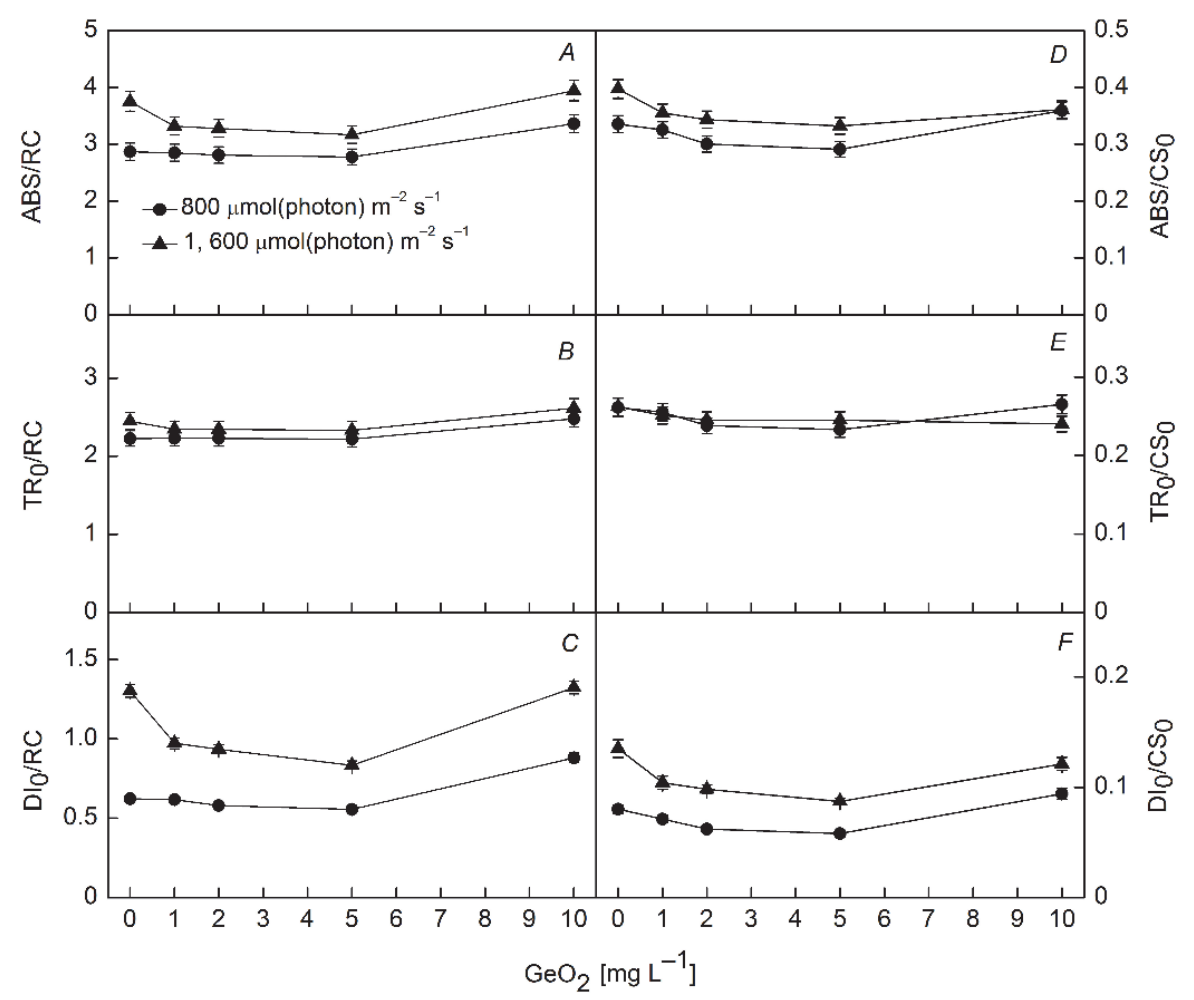

Fig. 3. Change in values of $(A) \mathrm{ABS} / \mathrm{RC},(B) \mathrm{TR}_{0} / \mathrm{RC},(C) \mathrm{DI}_{0} / \mathrm{RC},(D) \mathrm{ABS} / \mathrm{CS}_{0},(E) \mathrm{TR}_{0} / \mathrm{CS}_{0}$, and $(F) \mathrm{DI}_{0} / \mathrm{CS}_{0}$ in apple leaves under 800 and $1,600 \mu \mathrm{mol}$ (photon) $\mathrm{m}^{-2} \mathrm{~s}^{-1}$ for $4 \mathrm{~h}$ with different $\mathrm{GeO}_{2}$ concentrations.

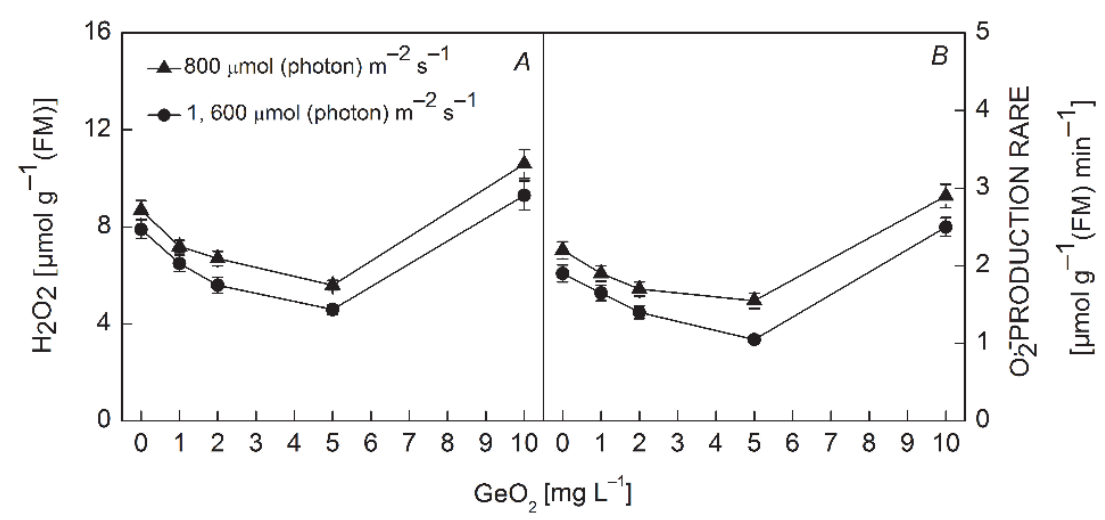

Fig. 4. Effect of different $\mathrm{GeO}_{2}$ concentrations on ROS content in apple leaves including $(A) \mathrm{H}_{2} \mathrm{O}_{2}$ content and $(B) \mathrm{O}_{2}{ }^{--}$content in apple leaves under 800 and $1,600 \mu \mathrm{mol}\left(\right.$ photon) $\mathrm{m}^{-2} \mathrm{~s}^{-1}$ for $4 \mathrm{~h}$.

\section{Discussion}

Regarding to the effects of Ge on plants, previous studies focused on the accumulation of $\mathrm{Ge}$ in medicinal herb or herbaceous plants and tried to find a critical toxicity value of this element (Halperin et al. 1995, Yu et al. 2005, Han et al. 2007, Lim et al. 2008, Cheong et al. 2009). Previous studies also found Ge could be helpful to scavenge ROS (Munakata et al. 1987), but it remains unclear on how Ge influences photosynthetic apparatus, in which ROS generates under high light and environmental stress. In this study, in order to reveal effects of $\mathrm{GeO}_{2}$ on photosynthesis and its mechanism, we monitored the response of apple leaves with different exogenous $\mathrm{GeO}_{2}$ treatment using $\mathrm{Chl}$ fluorescence, concentration or formation rate of ROS and activities of antioxidant enzymes.

Compared with the control, contents of inorganic and organic $\mathrm{Ge}$ in leaves treated with exogenous $\mathrm{GeO}_{2}$ increased significantly. After further analysis, we found that organic Ge content was the main form of Ge in apple leaves, although the exogenously applied Ge was in the inorganic form $\left(\mathrm{GeO}_{2}\right)$ (Table 1). It suggests that 


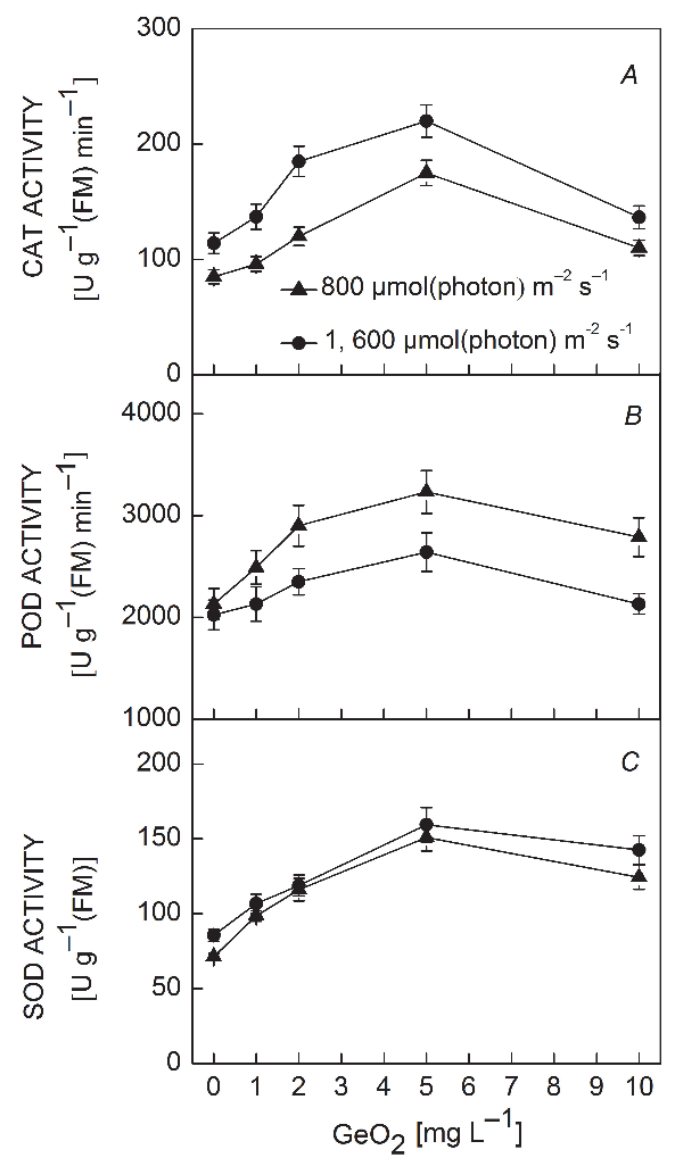

Fig. 5. Effect of different $\mathrm{GeO}_{2}$ concentrations on $(A)$ CAT activity, $(B)$ POD activity, $(C)$ SOD activity in apple leaves under 800 and $1,600 \mu \mathrm{mol}$ (photon) $\mathrm{m}^{-2} \mathrm{~s}^{-1}$ for $4 \mathrm{~h}$.

exogenous $\mathrm{GeO}_{2}$ converted into the organic form after entering into the apple leaves. The results are in accordance with studies in rice (Matsumoto et al. 1975).
Therefore, we speculate that the Malus has the capacity to change free inorganic form into a bound organic form.

The change of $\mathrm{Chl}$ contents implies exogenous $\mathrm{GeO}_{2}$ had a significant impact on $\mathrm{Chl} a$ content but not on $\mathrm{Chl} b$ content (Table 2). As Chl $a$ has the most important role among photosynthetic pigments, exogenous $\mathrm{GeO}_{2}$ may subsequently affect the function of photosynthetic apparatus which can be proved by modulated fluorescence parameters and fast fluorescence transient analysis.

As reported by previous researches, modulated fluorescence parameters could reflect photosynthetic performance including changes in PSII photochemistry efficiency, linear electron flux, and capacity of the Calvin cycle (Meyer et al. 2001). $\mathrm{F}_{\mathrm{v}} / \mathrm{F}_{\mathrm{M}}$, the maximum photochemical quantum yield of PSII, could provide a simple and rapid way to evaluate the photosynthetic performance (Henriques 2009, Zai et al. 2012, Zhang et al. 2014). In our study, $\mathrm{F}_{\mathrm{v}} / \mathrm{F}_{\mathrm{M}}$ of apple leaves with $1.0,2.0$, and $5.0 \mathrm{mg}\left(\mathrm{GeO}_{2}\right) \mathrm{L}^{-1}$ increased significantly and declined at $10.0 \mathrm{mg}\left(\mathrm{GeO}_{2}\right) \mathrm{L}^{-1}$ under both 800 and $1,600 \mu \mathrm{mol}$ (photon) $\mathrm{m}^{-2} \mathrm{~s}^{-1}$ (Table 3 ). Based on the changes of $\Phi_{\text {PSII }}$, $\mathrm{q}_{\mathrm{p}}, \mathrm{q}_{\mathrm{L}}$ and $\mathrm{F}_{\mathrm{v}}{ }^{\prime} / \mathrm{F}_{\mathrm{M}}$ ', we suggest $\mathrm{GeO}_{2}$ in appropriate concentration may facilitate the performance of photosynthetic apparatus. On the other hand, NPQ and $\mathrm{q}_{\mathrm{N}}$, quantifying energy dissipation through xanthophyll cycle and $\Delta \mathrm{pH}$ (Jahns and Holzwarth 2012), both declined in apple leaves with $1.0,2.0$, and $5.0 \mathrm{mg}\left(\mathrm{GeO}_{2}\right) \mathrm{L}^{-1}$ and rose with $10.0 \mathrm{mg}\left(\mathrm{GeO}_{2}\right) \mathrm{L}^{-1}$. Along with the rise of NPQ and $\mathrm{q}_{\mathrm{N}}, \Phi_{\mathrm{NPQ}}$ decreased at $1.0,2.0$ and $5.0 \mathrm{mg}\left(\mathrm{GeO}_{2}\right) \mathrm{L}^{-1}$ and increased at $10.0 \mathrm{mg}\left(\mathrm{GeO}_{2}\right) \mathrm{L}^{-1}$, while $\Phi_{\mathrm{NO}}$ remained at a steady level compared with control (Tab 1). If we consider $\Phi_{\mathrm{NPQ}}+\Phi_{\mathrm{NO}}+\Phi_{\mathrm{PSII}}=1$, the drop of $\Phi_{\mathrm{NPQ}}$ with 1.0, 2.0, and $5.0 \mathrm{mg}\left(\mathrm{GeO}_{2}\right) \mathrm{L}^{-1}$ resulted in the rise of $\Phi_{\mathrm{PSII}}$. Opposite response of photochemical capacity and energy dissipation indicates effects of $\mathrm{GeO}_{2}$ on photosynthetic apparatus.

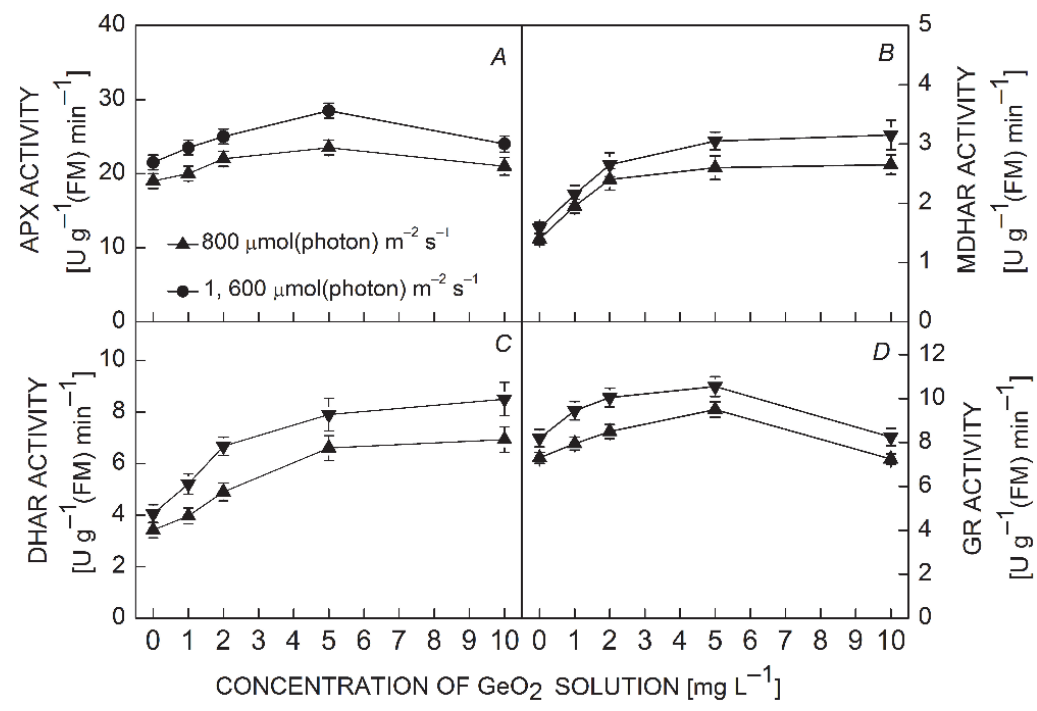

Fig. 6. Effects of different $\mathrm{GeO}_{2}$ concentrations on ascorbate-glutathione cycle including $(A)$ APX activity, $(B)$ MDHAR activity, $(C)$ DHAR activity, $(D)$ GR activity in apple leaves under 800 and $1,600 \mu \operatorname{mol}\left(\right.$ photon) $\mathrm{m}^{-2} \mathrm{~s}^{-1}$ for $4 \mathrm{~h}$. 
The fast fluorescence transient analysis is a fast and nondestructive method to measure the response of PSII activity to environmental changes and has been used widely for characterizing the photochemical quantum yield of PSII photochemistry and electron transport activity (Stirbet and Govindjee 2011, Schansker et al. 2005). In the present study, the JIP-test was also used to assess the photosynthetic performance of apple leaves with different $\mathrm{GeO}_{2}$ solutions under strong light (Fig. 1). The OJIP curves showed high light-induced decrease in apple leaves (Fig. 1B). This phenomenon was similar to Antarctic lichens under high light stress (Balarinová et al. 2014). The momentary maximum fluorescence intensity (J-step and I-step) represents the subsequent kinetic bottlenecks of the electron transport chain (Strasser et al. 2000, Lazár 2006). These limitations come from the exchange of a reduced plastoquinone molecule with an oxidized one at $\mathrm{Q}_{\mathrm{B}}$ site (J-step), and the reoxidation of plastoquinol ( $\mathrm{PQH}_{2}$, I-step) (Schansker et al. 2005). Such change of Chl fluorescence intensity in O-J, O-I, J-I phase can represent PETC activity between $\mathrm{Q}_{\mathrm{A}}-\mathrm{Q}_{\mathrm{B}}, \mathrm{Q}_{\mathrm{A}}-\mathrm{PSI}$ acceptor, $\mathrm{Q}_{\mathrm{B}}-\mathrm{PSI}$ acceptor, respectively (Wang et al. 2012). We found clearly the electron transport from $Q_{A}$ to $\mathrm{Q}_{\mathrm{B}}$, reflected by $1-\mathrm{V}_{\mathrm{J}}$ and $\mathrm{F}_{\mathrm{v}} / \mathrm{F}_{\mathrm{M}} \times\left(1-\mathrm{V}_{\mathrm{J}}\right)$, was affected more than the electron transport from $\mathrm{Q}_{\mathrm{B}}$ to PSI by exogenous $\mathrm{GeO}_{2}$ and two light intensities (Fig. 2).

In order to elucidate the performance of photosynthetic apparatus in more details, we applied the parameters derived from the $\mathrm{Chl} a$ fluorescence transient including $\mathrm{ABS} / \mathrm{RC}, \mathrm{ABS} / \mathrm{CS}_{0}, \mathrm{TR}_{0} / \mathrm{RC}, \mathrm{TR}_{0} / \mathrm{CS}_{0}, \mathrm{DI}_{0} / \mathrm{RC}, \mathrm{DI}_{0} / \mathrm{CS}_{0}$, to give a further insight into partitioning of absorbed light energy in apple leaves treated with $\mathrm{GeO}_{2}$. ABS/RC and $\mathrm{ABS} / \mathrm{CS}_{0}$, average absorbed photon flux per PSII RC and per CS, both presented a downward trend with 1.0, 2.0, $5.0 \mathrm{mg}\left(\mathrm{GeO}_{2}\right) \mathrm{L}^{-1}$, and then rose with $10.0 \mathrm{mg}\left(\mathrm{GeO}_{2}\right) \mathrm{L}^{-1}$ (Fig. $3 A, D$ ). $\mathrm{ABS} / \mathrm{RC}$ and $\mathrm{ABS} / \mathrm{CS}_{0}$ can be regarded as a probe to understand the average amount of absorbing antenna chlorophylls per fully active ( $\mathrm{Q}_{\mathrm{A}}$-reducing) reaction center, which offers a way to detect eventual inactivation of RCs. In the present study, those two parameters could tell that the number of $\mathrm{Q}_{\mathrm{A}}$-reducing $\mathrm{RCs}$ and the density of RCs per CS in control and $10.0 \mathrm{mg} \mathrm{L}^{-1}$ group were lower than those at 1.0, 2.0 and $5.0 \mathrm{mg}\left(\mathrm{GeO}_{2}\right)$ $\mathrm{L}^{-1}$. Irradiance of $1,600 \mu \mathrm{mol}$ (photon) $\mathrm{m}^{-2} \mathrm{~s}^{-1}$ can more easily inactivate PSII RC than that of $800 \mu \mathrm{mol}$ (photon) $\mathrm{m}^{-2} \mathrm{~s}^{-1}$ therefore under high irradiation, the number of $\mathrm{Q}_{\mathrm{A}^{-}}$ reducing $\mathrm{RCs}$ were lower in apple leaves. It can explain $\mathrm{ABS} / \mathrm{RC}$ and $\mathrm{ABS} / \mathrm{CS}_{0}$ under $1,600 \mu \mathrm{mol}$ (photon) $\mathrm{m}^{-2} \mathrm{~s}^{-1}$ were higher than those under $800 \mu \mathrm{mol}$ (photon) $\mathrm{m}^{-2} \mathrm{~s}^{-1}$. $\mathrm{TR}_{0} / \mathrm{RC}$ and $\mathrm{TR}_{0} / \mathrm{CS}_{0}$ (Fig. $3 B, E$ ) in our study did not change remarkably with different exogenous $\mathrm{GeO}_{2}$ solutions and different light intensities. Data of $\mathrm{DI}_{0} / \mathrm{RC}$ and $\mathrm{DI}_{0} / \mathrm{CS}_{0}$ (Fig. 3C,F) showed that dissipated energy per PSII RC and CS dropped significantly, This also suggests that high irradiation declines photoprotection capacity. Apparently, $\mathrm{GeO}_{2}$ application in range of values of 1.0 $5.0 \mathrm{mg} \mathrm{L}^{-1}$ resulting in apple leaves absorbing less light energy and dissipating more energy per PSII RC and CS, which reduced the damage of strong light to photosynthetic apparatus. However, it also did not exclude the possibility for downregulation of photosynthetic excitation pressure (Li et al. 2015).

As the site of photosynthesis, chloroplasts are also the major source of ROS such as $\mathrm{O}_{2}{ }^{-}$and $\mathrm{H}_{2} \mathrm{O}_{2}$. ROS can be generated by the direct transfer of the excitation energy from $\mathrm{Chl}$ to produce singlet oxygen or by oxygen reduction in the Mehler reaction in the chloroplasts, leading to membrane lipid peroxidation (Stepien and Klobus 2005, Gill and Tuteja 2010). In our study, we observed apple leaves treated with $1.0,2.0$, and $5.0 \mathrm{mg}\left(\mathrm{GeO}_{2}\right) \mathrm{L}^{-1}$ accumulated less $\mathrm{O}_{2}^{-}$and $\mathrm{H}_{2} \mathrm{O}_{2}$ (Fig. 4), which could be responsible for the increase of photosynthetic performance.

During evolution, a serious of antioxidant enzymes are developed to scavenge ROS in plants. Concisely, SOD plays a central role in the enzymatic defense system in removing $\mathrm{O}_{2}^{-}$(Diao et al. 2014) and CAT has a potential to directly dismutate $\mathrm{H}_{2} \mathrm{O}_{2}$ into $\mathrm{H}_{2} \mathrm{O}$ and $\mathrm{O}_{2}$, which is indispensable for ROS-detoxification (Garg and Manchanda 2009, Hasanuzzaman and Fujita 2011). So to figure out the reason for the decreased contents of ROS, we determined the activities of antioxidant enzymes. In our study, with low concentration of $\mathrm{GeO}_{2}$ treatment, CAT, SOD and POD activities increased, especially the activities of CAT and POD were noticeably higher under high light intensity (Fig. 5). Apart from CAT, POD and SOD, it is well known that the ascorbate-glutathione cycle is the key mechanism to scavenge ROS in plant chloroplasts and its higher efficiency under abiotic and biotic stress is responsible for the alleviation of oxidant damage to chloroplasts (Nakano and Asada 1981). In this cycle, APX plays the most important role in removing $\mathrm{H}_{2} \mathrm{O}_{2}$. MDHAR, DHAR, and GR are mainly responsible for providing substrates for APX through the formation of reduced AsA and GSH. Our results showed that exogenous $\mathrm{GeO}_{2}$ below $5.0 \mathrm{mg} \mathrm{\textrm {L } ^ { - 1 }}$ promoted the activities of APX, MDHAR, DHAR and GR (Fig. 6). Such response of antioxidant defense system may be a protecting mechanism for apple leaves through improving the activity to clear excess ROS under strong light.

In this study, we investigated effects of $\mathrm{GeO}_{2}$ on photosynthetic performance of apple leaves under strong light. With the application of $\mathrm{GeO}_{2}$, the photosynthetic performance of apple leaves including maximum photochemical quantum yield of PSII, the actual photochemical quantum yield of PSII and photochemical quenching efficiency at $1.0,2.0$, and $5.0 \mathrm{mg}\left(\mathrm{GeO}_{2}\right) \mathrm{L}^{-1}$ remarkably increased under both light intensities. In the meantime, dissipated energy through xanthophyll cycle and $\Delta \mathrm{pH}$ decreased noticeably compared with the control when the $\mathrm{GeO}_{2}$ concentration was below $5.0 \mathrm{mg} \mathrm{L}^{-1}$. Also, PETC capacity was also found to be impacted by exogenous $\mathrm{GeO}_{2}$ among $\mathrm{Q}_{\mathrm{A}}-\mathrm{Q}_{\mathrm{B}}, \mathrm{Q}_{\mathrm{A}}-\mathrm{PSI}$ acceptor, and $\mathrm{Q}_{\mathrm{B}}-\mathrm{PSI}$ acceptor, PETC happened in $\mathrm{Q}_{\mathrm{A}}$ to $\mathrm{Q}_{\mathrm{B}}$ was affected the most showing a rising trend with low concentration of $\mathrm{GeO}_{2}$ teatment. The decrease in ROS accumulation and 
increase of antioxidant enzymatic defense system might be the reason for the drop of dissipated energy and the promotion of photosynthetic performance in apple leaves treated with $\mathrm{GeO}_{2}$ solution below $5.0 \mathrm{mg} \mathrm{L}{ }^{-1}$. As organic

\section{Reference}

Adams J.H., Thomas D.: Germanium and germanium compounds. - In: Kirk-Othmer (ed.): Encyclopedia of Chemical Technology. Pp. 540-555. Wiley, New York 1994.

Apel K., Hirt H.: Reactive oxygen species: metabolism, oxidative stress, and signal transduction. - Annu. Rev. Plant Biol. 55: 373-399, 2004.

Balarinová K., Barták M., Hazdrová J. et al.: Changes in photosynthesis, pigment composition and glutathione contents in two Antarctic lichens during a light stress and recovery. Photosynthetica 52: 538-547, 2014.

Bilger W., Björkman O.: Role of the xanthophyll cycle in photoprotection elucidated by measurements of light-induced absorbance changes, fluorescence and photosynthesis in leaves of Hedera canariensis. - Photosynth. Res. 25: 173-185, 1990.

Chen C., Li H., Zhang D. et al.: The role of anthocyanin in photoprotection and its relationship with the xanthophyll cycle and the antioxidant system in apple peel depends on the light conditions. - Physiol. Plantarum 149: 354-366, 2013.

Cheong Y.H., Kim S.U., Seo D.C. et al.: Effect of inorganic and organic germanium treatments on the growth of lettuce (Lactuca sativa). - J. Korean Soc. Appl. Bi. 52: 389-396, 2009.

Díaz-Vivancos P., Clemente-Moreno M.J., Rubio M. et al.: Alteration in the chloroplastic metabolism leads to ROS accumulation in pea plants in response to plum pox virus. $-\mathrm{J}$. Exp. Bot. 59: 2147-2160, 2008

Diao M., Ma L., Wang J.W.: Selenium promotes the growth and photosynthesis of tomato seedlings under salt stress by enhancing chloroplast antioxidant defense system. - J. Plant Growth Regul. 33: 671-682, 2014.

Garg N., Manchanda G.: ROS generation in plants: boon or bane? - Plant Biosyst. 143: 81-96, 2009.

Genty B., Briantais J.M., Baker N.R.: The relationship between the quantum yield of photosynthetic electron transport and quenching of chlorophyll fluorescence. - Biochim. Biophys. Acta 990: 87-92, 1989

Gill S.S., Tuteja N.: Reactive oxygen species and antioxidant machinery in abiotic stress tolerance in crop plants. - Plant Physiol. Bioch. 48: 909-930, 2010.

Goodman S.: Therapeutic effects of organic germanium. - Med. Hypotheses 26: 207-215, 1988.

Halperin S.J., Barzilay A., Carson M. et al:: Germanium accumulation and toxicity in barley. - J. Plant Nutr. 18: 1417$1426,1995$.

Han M.J., Kim S.U., Seo D.C. et al.: Uptake properties of germanium to vegetable plants and its effect on seed germination and on early stage growth. - Korean J. Environ. Agric. 26: 217-222, 2007.

Hasanuzzaman M., Fujita M.: Selenium pretreatment upregulates the antioxidant defense and methylglyoxal detoxification system and confers enhanced tolerance to drought stress in rapeseed seedlings. - Biol. Trace Elem. Res. 143: 1758-1776, 2011.

Henriques F.S.: Leaf chlorophyll fluorescence: background and fundamentals for plant biologists. - Bot. Rev. 75: 249-270, 2009.
Ge has been reported to have a function scavenging free radicals, such response of antioxidant ability under strong light could be related to the transformation of Ge chemical form, from exogenous inorganic $\mathrm{GeO}_{2}$ to organic $\mathrm{Ge}$.

Jahns P., Holzwarth A.R.: The role of the xanthophyll cycle and of lutein in photoprotection of photosystem II. - Biochim. Biophys. Acta 1817: 182-193, 2012.

Kaplan B.J., Parish W.W., Andrus G.M. et al.: Germane facts about germanium sesquioxide: I. Chemistry and anticancer properties. - J. Altern. Complem. Med. 10: 337-344, 2004.

Kitajima M., Butler W.L.: Quenching of chlorophyll fluorescence and primary photochemistry in chloroplasts by dibromothymoquinone. - Biochim. Biophys. Acta 376: 105-115, 1975.

Kramer D.M., Johnson G., Kiirats O., Edwards G.E.: New fluxparameters for the determination of $\mathrm{Q}_{\mathrm{A}}$ redox state and excitation fluxes. - Photosynth. Res. 79: 209-218, 2004.

Lazár D.: The polyphasic chlorophyll $a$ fluorescence rise measured under high intensity of exciting light. - Funct. Plant Biol. 33: 9-30, 2006.

Lichtenthaler H.K.: Chlorophylls and carotenoids: pigments of photosynthetic biomembranes. - Methods Enzymol. 148: 350$382,1987$.

Li L., Zhou Z., Liang J., Lv R.: In vivo evaluation of the highirradiance effects on PSII activity in photosynthetic stems of Hexinia polydichotoma. - Photosynthetica 53: 621-624, 2015.

Lim J.S., Seo D.C., Park W.Y. et al.: Effects of soil texture on germanium uptake and growth in rice plant by soil application with germanium. - Korean J. Environ. Agric. 27: 245-252, 2008.

Liu Y., Hou L.Y., Li Q.M. et al.: The effects of exogenous antioxidant germanium $(\mathrm{Ge})$ on seed germination and growth of Lycium ruthenicum Murr subjected to $\mathrm{NaCl}$ stress. Environ. Technol. 37: 909-919, 2016.

Matsumoto H., Syo S., Takahashi E.: Translocation and some forms of germanium in rice plants. - Soil Sci. Plant Nutr. 21: 273-279, 1975

McMahon M., Regan F., Hughes H.: The determination of total germanium in real food samples including Chinese herbal remedies using graphite furnace atomic absorption spectroscopy. - Food Chem. 97: 411-417, 2006.

Meyer S., Saccardy-Adji K., Rizza F., Genty B.: Inhibition of photosynthesis by Colletotrichum lindemuthianum in bean leaves determined by chlorophyll fluorescence imaging. Plant Cell Environ. 24: 947-955, 2001.

Munakata T., Agai S., Kuwano K. et al.: Induction of interferon production by natural killer cells by organogermanium compound Ge-132. - J. Interferon Res. 7: 69-76, 1987.

Nakano Y., Asada K.: Hydrogen peroxide is scavenged by ascorbate-specific peroxidase in spinach chloroplasts. - Plant Cell Physiol. 22: 867-880, 1981.

Nickel R.S., Cunningham B.A.: Improved peroxidase assay method using leuco 2,3,6-trichloroindophenol and application to comparative measurements of peroxidase catalysis. - Anal. Physiol. 172: 385-390, 1969.

Rao K.V.M., Sresty T.V.S.: Antioxidant parameters in the seedlings of pigeon pea (Cajanus cajan L. Millspaugh) in response to Zn and Ni stresses. - Plant Sci. 157: 113-128, 2000.

Rosenberg E.: Germanium: environmental occurrence, importance and speciation. - Rev. Environ. Sci. Bio. 8: 29-57, 2009. 
Schansker G., Tóth S.Z., Strasser R.J.: Methylviologen and dibromothymoquinone treatments of pea leaves reveal the role of photosystem I in the Chl $a$ fluorescence rise OJIP. Biochim. Biophys. Acta 1706: 250-261, 2005.

Schreiber U., Schliwa U., Bilger W.: Continuous recording of photochemical and non-photochemical chlorophyll fluorescence quenching with a new type of modulation fluorometer. Photosynth. Res. 10: 51-62, 1986.

Seo D.C., Cheon Y.S., Park S.K. et al.: [Applications of different types of germanium compounds on rice plant growth and its Ge uptake.] - Korean J. Soil Sci. Fertil. 43: 166-173, 2010. [In Korean]

Sparks J.P., Chandra S., Derry L.A. et al.: Subcellular localization of silicon and germanium in grass root and leaf tissues by SIMS: evidence for differential and active transport. Biogeochemistry 104: 237-249, 2011.

Stepien P., Klobus G.: Antioxidant defense in the leaves of C3 and $\mathrm{C} 4$ plants under salinity stress. - Physiol. Plantarum 125: 31-40, 2005.

Stirbet A., Govindjee: On the relation between the Kautsky effect (chlorophyll $a$ fluorescence induction) and photosystem II: Basics and applications of the OJIP fluorescence transient. - J. Photoch. Photobio. B 104: 236-257, 2011.

Strasser R.J.A., Srivastava A., Tsimilli-Michael M.: The fluorescence transient as a tool to characterize and screen photosynthetic samples. - In: Yunus M., Pathre U., Mohanty P. (ed.): Probing Photosynthesis: Mechanisms, Regulation and Adaptation. Pp. 445-483. Taylor and Francis, London 2000.

Takahashi S., Murata N.: How do environmental stresses accele- rate photoinhibition? - Trends Plant Sci. 13: 178-182, 2008.

Tang Z., Shi Y., Zhou J.P. et al.: Effects of an organogermanium compound on antioxidant function of vMDV-infected chickens. - Chinese J. Vet. Sci. 17: 173-176, 1997. [In Chinese]

Tarakhovskaya E.R., Kang E.J., Kim K.Y., Garbary D.J.: Effect of $\mathrm{GeO}_{2}$ on embryo development and photosynthesis in Fucus vesiculosus (Phaeophyceae). - Algae 27: 125-134, 2012.

Yang M.K., Kim Y.G.: Protective role of germanium-132 against paraquat-indrced oxidative stress in the livers of senescence accelerated mice. - J. Toxicol. Environ. Health A 58: 289-297, 1999.

Wang Z.X., Chen L., Ai J. et al.: Photosynthesis and activity of photosystem II in response to drought stress in Amur Grape (Vitis amurensis Rupr.). - Photosynthetica 50: 189-196, 2012.

Yu K.W., Murthy H.N., Jeong C.S. et al.: Organic germanium stimulated the growth of ginseng dventitious roots and ginsenoside production. - Process. Biochem. 40: 2959-2961, 2005.

Zai X.M., Zhu S.N., Qin P. et al.: Effect of Glomus mosseae on chlorophyll content, chlorophyll fluorescence parameters, and chloroplast ultrastructure of beach plum (Prunus maritima) under $\mathrm{NaCl}$ stress. - Photosynthetica 50: 323-328, 2012.

Zhang J.X., Kirkham M.B.: Antioxidant responses to drought in sunflower and sorghum seedlings. - New Phytol. 132: 361-373, 1996.

Zhang M., Tang S.U., Huang X. et al.: Selenium uptake, dynamic changes in selenium content and its influence on photosynthesis and chlorophyll fluorescence in rice (Oryza sativa L.). - Environ. Exp. Bot. 107: 39-45, 2014. 